\title{
Malaria and COVID-19 in Malarial Endemic Area: Incidence and Coincidence
}

\author{
Stmanin Endemik Bölgesinde Sitma ve COVID-19: Insidans ve Tesadüf \\ (1) Rujittika Mungmunpuntipantip ${ }^{1}$, (1) Viroj Wiwanitkit ${ }^{2}$ \\ ${ }^{1}$ Consultant Center, Private Academic Consultant, Bangkok, Thailand \\ ${ }^{2}$ Department of Community Medicine, Dr DY Patil University, Pune, India
}

Cite this article as: Mungmunpuntipantip R, Wiwanitkit V. Malaria and COVID-19 in Malarial Endemic Area: Incidence and Coincidence. Turkiye Parazitol Derg 2022;46(1):84-85.

\section{Dear Editor,}

Interrelationship between parasitic disease and Coronavirus disease-2019 (COVID-19) is an interesting clinical issue. In the recent publication (1), the possible association between COVID-19 and liver fluke infestation is discussed. In addition to helminthiasis, the association between blood parasite and COVID-19 is interesting. Malaria is the important blood parasitic infection. It is common in tropical area. Regarding malaria, antimalarial drugs are widely mentioned on their possible role against COVID-19 (2).

Here, the authors discuss on incidence and coincidence malaria and COVID-19 in a malarial endemic area in Indochina. The setting is the second area of the world which has been affected by COVID-19 since January 2020. At present (2021), there are more than 1 million COVID-19 cases. Since this area is also an endemic area of malaria, it is interesting to assess the incidence of both diseases. Data from a border province with another Indochina country, Cambodia, are retrospectively analyzed. In this province (GPS location 14.87346, 103.67555), malaria is still important problem. Four from seventeen districts of this province are considered malarial endemic area. The incidence of malaria and COVID-19 in year 2021 is presented in Table 1.

\section{Table 1. Incidence of malaria and COVID-19 (year 2021 data from local CDC)}

\begin{tabular}{|l|l|l|l|l|}
\hline District & $\begin{array}{l}\text { Malaria endemic } \\
\text { area }\end{array}$ & $\begin{array}{l}\text { Incidence of } \\
\text { malaria }\end{array}$ & $\begin{array}{l}\text { Incidence of } \\
\text { COVID }\end{array}$ & $\begin{array}{l}\text { Incidence of } \\
\text { malaria and COVID } \\
\text { coinfection }\end{array}$ \\
\hline BC & Yes & 64 & 2 & 0 \\
SK & Yes & 5 & 7 & 0 \\
DR & Yes & 55 & 2 & 0 \\
KC & Yes & 0 & 10 & 0 \\
MU & No & 0 & 20 & 0 \\
PS & No & 0 & 15 & 0 \\
CP & No & 0 & 16 & 0 \\
SK & No & 0 & 13 & 0 \\
CP & No & 0 & 10 & 0 \\
RB & No & 0 & 10 & 0 \\
KS & No & 0 & 5 & 0 \\
TT & No & 0 & 5 & 0 \\
ST & No & 0 & 4 & 0 \\
SN & No & 0 & 3 & 0 \\
LD & No & 0 & 1 & 0 \\
SR & No & 0 & \\
NN & No & & \\
\hline COVID: Coronavirus, COVID-19: Coronavirus disease- 2019, CDC: Centers for disease control &
\end{tabular}

Received/Geliş Tarihi: 02.11.2021 Accepted/Kabul Tarihi: 04.11.2021

Address for Correspondence/Yazar Adresi: Rujittika Mungmunpuntipantip, Consultant Center, Private Academic Consultant, Bangkok, Thailand

Phone/Tel: +68328328822 E-mail/E-Posta: rujittika@gmail.com ORCID ID: orcid.org/0000-0003-0078-7897 
Indeed, the incidence of COVID-19 in the studied malarial endemic province is significantly less than other areas of the country. Focusing on details, districts where malaria is endemic usually have a lower incidence of malaria than the district where malaria is not endemic. Whether there is any possible biological mechanism of Plasmodium spp. against severe acute respiratory syndrome-coronavirus- 2 is interesting question. Also, whether it is an effect of local malaria chemoprophylaxis is an issue for further researching. However, an interesting observation is no coincidence of malaria and COVId-19. The co-infection is reported in some literatures $(3,4)$. However, we found no coincidence. Based on the local, national prevalence of malaria and COVID-19 are 3.18 and 0.22 per 100,000 local populations, respectively (data according to local CDC, https:// ddc.moph.go.th/), coinfection should be possible. Further realworld epidemiological study for association between malaria and COVID-19 is recommended.

Keywords: Malaria, COVID-19, incidence, coincidence Anahtar Kelimeler: Sitma, COVID-19, insidans, tesadüf

\section{*Ethics}

Peer-review: Internally peer-reviewed.

* Authorship Contributions

Concept: R.M., V.W., Design: R.M., V.W., Data Collection or Processing: R.M., V.W., Analysis or Interpretation: R.M., V.W., Writing: R.M., V.W.

Conflict of Interest: No conflict of interest was declared by the authors.

Financial Disclosure: The authors declared that this study received no financial support.

\section{REFERENCES}

1. Mungmunpuntipantip R, Wiwanitkit V. Relationship Between Prevalence of Opisthorchiasis and Incidence of COVID-19: An Observation. Turkiye Parazitol Derg 2021; 45: 230.

2. Zang Y, Han X, He M, Shi J, Li Y. Hydroxychloroquine use and progression or prognosis of COVID-19: a systematic review and meta-analysis. Naunyn Schmiedebergs Arch Pharmacol 2021; 394: 775-82.

3. Pusparani A, Henrina J, Cahyadi A. Co-infection of COVID-19 and recurrent malaria. J Infect Dev Ctries 2021; 15: 625-9.

4. Sardar S, Sharma R, Alyamani TYM, Aboukamar M. COVID-19 and Plasmodium vivax malaria co-infection. IDCases 2020; 21: e00879. 